\title{
LEITURAS DA CIDADE E EDUCAÇÃO
}

\author{
MARY JULIA MARTINS DIETZSCH \\ Faculdade de Educação da Universidade de São Paulo \\ mdietzsc@usp.br
}

\begin{abstract}
RESUMO
No artigo, a cidade moderna é focalizada como um modo de existência da sociedade, como um espaço polifônico e em suas relações com a educação. Mais que uma paisagem geográfica, reforça-se a idéia de cidade como um símbolo a ser desvendado, como o lugar que deverá ser o do cidadão. Nesse sentido, vale questionar: O que é ser cidadão hoje? Quem tem a palavra na cidade moderna? Na tentativa de descobrir as muitas cidades, que coexistem ou se antagonizam na megalópole, demos a palavra a representantes de diferentes grupos sociais para que expressassem as imagens que fazem de São Paulo. Abordamos neste texto quatro desses grupos, constituídos por pequenos lavradores, por meninos/meninas que vivem nas ruas da cidade, por alunos de escolas da periferia urbana e jovens cantores de rap. O registro das falas e imagens de cada um dos grupos foi sintetizado nas categorias: "a cidade imaginada", "a cidade vista de longe", "o desencanto da cidade" e "a cidade contestada".

RELAÇÕES ESCOLA-COMUNIDADE - CIDADANIA - SÃO PAULO
\end{abstract}

\section{ABSTRACT}

READINGS OF THE CITY AND EDUCATION. In this study, modern city is focused as one of society's way of existence, as a polyphonic space and in its relations with Education. More than a geographical landscape, it is reinforced the idea of city as a symbol to be disclosed, as a place that should be that of the citizen. In this sense, it is worth to question: What is to be a citizen today? Who owns the word in modern city? And, in the attempt to discover the cities which co-exist or antagonize themselves in the megalopolis we invite people from different social groups to express the images they make of a big city like São Paulo. In this text, four of these groups - those constituted by small peasants, boys and girls that live in the streets, students of suburban schools and young rappers singers - were discussed. The speeches and the images of each group were synthesized in the following categories of analyses: the "imagined city", "the city seen from a far distance", the "disenchantment of the city" and the "contested city".

SCHOOL COMMUNITY RELATIONSHIP - CITIZENSHIP - SÃO PAULO 
São Paulo! Comoção de minha vida... Os meus amores são flores feitas de original... Arlequinal!... Traje de losangos... cinza e ouro...

Luz e bruma... forno e inverno morno... Elegáncias sutis sem escândalos, sem ciúmes...

Perfumes de Paris... Arys! Bofetadas no Trianon... Algodoal!... São Paulo! Comoção de minha vida... Galicismo a berrar nos desertos da América! Mario de Andrade, 1922

Em seu canto, Mario percorre a cidade. Obstinado, descobre lugares, atravessa largos, perscruta os transeuntes. E na São Paulo dos anos 30 observa as "aristocracias cautelosas" e já se despede de um rio, o Tietê, "que era uma vez... Nos Parques do Anhangabaú ouve sapos que cantam suas Maguas: 'Meu pai foi rei! - foi. \% Não foi. - Foi. Não foi' ". Na entoação do poeta subjaz a leitura de quem conhece São Paulo; de quem fala e escreve a cidade, para desvendar suas muitas faces. Na cadência poética, ressoa a voz do cidadão.

Quando se considera que diferentes e distantes cidades se escondem na metrópole, faz-se importante buscar tais diferenças em uma leitura que permita desvendar os lugares que nem sempre se expõem à vista. E quem poderia mediar e diferenciar a distância entre essas muitas cidades, senão o cidadão? Melhor dizendo, um homem que para além da "cidadania passiva" outorgada pelo Estado se constitui ativamente por meio de seus direitos e deveres e que, essencialmente, se apresenta como um criador de direitos a abrir espaços para participação, ou seja: para a "cidadania ativa" (Chaui, 1984).

Mais do que simplesmente uma paisagem geográfica, a cidade se apresenta como um símbolo inesgotável da existência humana, como o lugar que deveria e deverá ser o do cidadão: daquele que habita a cidade. Para muito além de um mapa, a cidade tem o sentido de uma rede a permitir o traçado de múltiplos fios que se emaranham em vozes e significações, e é como um texto, a sugerir muitas leituras que a cidade pode oferecer suas imagens e sentidos em dispersão. Parafraseando Eduardo Portela:

Por trás da cartografia, ou da mera organização do espaço físico, retirando-a do seu repouso inútil ou da sua agitação predatória, persiste a trama infatigável de imaginação e memória, no encalço da comunidade de cidadãos. (1995, p. I l 0 ) 
Nos momentos de grandeza da cidade grega, da polis e das cidadesEstados romanas encontram-se as origens clássicas do conceito de cidadania. E do termo grego, polis, traduzido pelos romanos para civis - civitas, nos chegam as palavras: cidadão, cidadania ou multidão de cidades. Na história das cidades, situações diferentes identificam o que é ser cidadão, mas é no final do século VI a.C., com o avanço da democracia ateniense, que vai se delineando a idéia de uma cidade livre. A vida política de Atenas testemunha um equilíbrio entre os direitos de indivíduos e o poder público e é nesse momento que alguns homens, reunidos na praça pública, decidem sobre os destinos da cidade.

Na ágora e nas assembléias, a palavra é do cidadão, de homens que habitam a cidade!. "Quem pede a palavra?", pergunta o arauto, dando início à deliberação. E o cidadão chamado a ocupar a tribuna põe sobre a cabeça uma coroa de mirta, tornando-se, assim, inviolável e sagrado. Era com a discussão e com a palavra que cada um aprendia, pela prática, o ofício de cidadão, seus deveres e direitos. Chegou, no entanto, um tempo em que, na escala dos valores, a eloqüência colocou-se bem acima da sabedoria e fatores, os mais diversos, foram levando a cidade à decadência. E a palavra volta, assim, a ser privilégio de alguns como já o fora anteriormente, e continuará sendo na cidade de hoje, quase sem exceção.

Na tangência dessas questões, não se pretende, neste trabalho, aprofundar a idéia de cidade e do que é ser cidadão ao longo da história humana. A tentativa é buscar alguma aproximação com as nossas cidades de hoje, em um percurso que possibilite posições mais atentas e flexíveis ao desvendamento de imagens, vozes e caminhos que se cruzam na metrópole. A cidade será então focalizada em mais de um sentido: de um lado como um modo de existência da sociedade; de outro, como um espaço a ser alcançado em sua polifonia. E além disso, como um lugar a ser retomado em suas relações com a educação e com a cidadania.

Na construção dessa leitura da cidade em suas relações com a educação, que se atente à História e às histórias que fazem da metrópole um lugar

I. Embora o debate se desse na praça pública, era muito pequeno o número dos que utilizavam da prerrogativa de tomar a palavra. Em regra, os chefes de partido e os seus loco-tenentes eram os que arcavam com o ônus do debate, como assinala Gustave Glotz (1980, p. I33). 
do homem e, portanto, um lugar da palavra e da linguagem, em suas muitas possibilidades, como o fora na cidade grega de outrora. Quando se admite que por trás da cidade que se vê, há uma outra invisível a ser desvendada, é, no mínimo ingênuo, pretender aproximar-se da metrópole sem que se tente a leitura dessa cidade subjetiva que não se expõe de pronto à vista. Como lembra Italo Calvino

Em toda a sua extensão, a cidade parece continuar a multiplicar o seu repertório de imagens: no entanto, não tem espessor, consiste somente de um lado de fora de um avesso, como uma folha de papel, com uma figura aqui e outra ali, que não podem se separar nem se encarar. (1992, p. 97)

Para ensinar a metropóle, é preciso conhecê-la, ou pelo menos ter consciência de sua legibilidade e da complexidade de seu texto. Babel, esfinge, ou labirinto, a megalópole pressupõe multiplicidade de caminhos e pluralidade de leituras para a interpretação de suas questões que podem parecer ininteligíveis, tortuosas e devoradoras. No entanto, mencionando o mito grego, vale lembrar que, aliado à força sublime da ação heróica, é o amor de Ariadne com o segredo de seus fios - metáforas do conhecimento - que auxiliam o herói ateniense no combate e que o conduzem de volta, através dos caminhos retorcidos da construção de Dédalo.

Pode ser que a cidade seja a realização do antigo sonho humano do labirinto, como preconiza Benjamin (1991). Entretanto, nessa selva social, pouco afeita a ações heróicas, o enfrentamento não será a resposta. Melhor poderá ser o fio do conhecimento e um desejo que se transfigura em gestos de aproximação. Chegar mais perto, seguir e inverter caminhos, atentar para vozes que circulam pela megalópole. Ao final, talvez o vislumbre das muitas "cidades que se escondem na cidadela". Desvendar, mais que enfrentar e querer, mais que repudiar, são ações e sentimentos que trazem à mostra a cidade antropofágica, ou uma outra pródiga, e inspiradora de sonhos.

Para a compreensão da cidade como um símbolo inesgotável da existência humana e o entendimento de sua polifonia, dar voz à cidade não seria uma forma de se iniciar a leitura de seu texto? Polifonia referida no contraponto entre o que Massimo Canevacci (1993, p. 17) entende por comunicação urbana e as vozes que expressam as diferentes formas de o homem ver a cidade: 
... a cidade em geral e a comunicação urbana em particular comparam-se a um coro que canta com uma multiplicidade de vozes autônomas que se cruzam, relacionam-se, sobrepõem-se umas às outras, isolam-se ou se contrastam; e também designa uma determinada escolha metodológica de "dar voz a muitas vozes", experimentando assim um enfoque polifônico com o qual se pode representar o mesmo objeto - justamente a comunicação urbana. A polifonia está no objeto e no método...

Portanto, para olhar e ouvir a cidade sob o prisma de vários lugares e tempos, em diferentes perspectivas, nada mais pertinente que o delinear de um caminho que possibilite a escuta das vozes que ecoam, ou apenas sussurram, nos diferentes espaços de uma megalópole moderna, como São Paulo. No suceder contraditório de tempos, marcas e marcos, é possível que se vislumbrem não apenas o homem com suas memórias, sonhos e força criadora, mas também com seus vícios, seus medos e desesperanças.

Não basta apenas percorrer a cidade, transitar por seus espaços para entender sua linguagem. Os caminhos desse labirinto requerem sua Ariadne e não apenas a exibição de mapas e estatutos feitos de papel. Quando a cidade cuida mais de sua escrita, do seu traçado, do que de seus leitores, seu texto perde o sentido, se enfraquecem os cidadãos. E sem oportunidade para interpretar, transformar e organizar o seu meio, o homem gasta-se no imediato com risco de ir-se apagando a força de sua imaginação.

Em suas astúcias e fetiches a cidade moderna é tanto um lugar de riscos e enganos, quanto um espaço por onde circula a arte, a cultura: frutos da obra e da imaginação humana. É assim a metrópole, que abriga em suas ruas degradadas e em seus bairros ajardinados a "distância" entre suas muitas cidades. Vale lembrar que a ultrapassagem de tais fronteiras requer senhas e códigos, cujo desconhecimento pode significar embustes e falências. Quando vista em sua totalidade, a megalópole se rompe em ilhas de opulência e em detritos de exclusão. Dilacera-se em lugares de tensão por onde podem circular, não apenas as desigualdades e a miséria, mas também a lembrança de um tempo passado, a esperança da hora presente, a fluidez do sonho e da imaginação.

Assim, determinando as diferentes visões de seus habitantes, a metrópole pode-se confirmar como um lugar de privilégios ou de restrições. Marcada pela intensa concentração populacional e pelas contradições sociais, a me- 
trópole pode explodir, projetando seus fragmentos em espetáculos que encenam não apenas a violência, e a miséria, mas também a arrogância do luxo e do consumo. Se o espetáculo do luxo e do consumo é explicado sem maiores rodeios, ou visto a quem interessa, como um fenômeno natural, como sair da abstração e explicar o dilaceramento e a violência em megalópoles, das quais São Paulo é um exemplo?

Existe um mito da não-violência do brasileiro, segundo o qual ele odeia a violência e não é violento, como afirma Marilena Chaui (1984). Segundo esse mito se a violência existe ela é praticada pelos pobres, pelos desnaturados sem nome que ferem a vida urbana. Em um mascaramento da violência e autoritarismo quotidianos, as relações sociais, as desigualdades econômicas, as exclusões políticas e culturais perdem seu caráter histórico para serem vistas como naturais. Uma vez que a divisão social entre privilegiados e "os outros" aparece como natural, legitimam-se mazelas como desemprego, fome, falta de moradia, analfabetismo, discriminação racial, destruição do meio ambiente.

Nessa ideologia do mascaramento, pode parecer natural que crianças pobres, filhas de "pais analfabetos e ignorantes", sejam reprovadas e abandonem a escola. A violência não está na escola que negligencia o ensino, mas na criança e em seu ambiente cultural; natural é também que pais esperem horas por um diretor e professores que não têm tempo para atendê-lo; pouco importa ainda que professora substituta seja informada, no começo do ano letivo, que naquela escola não há mais lugar para ela. Mais do que a crítica, é a naturalidade que permeia inúmeras ações que ocorrem não apenas na escola, mas também nos hospitais, nos órgãos policiais e tantas outras instituições públicas.

Pode ainda soar como legítimo o fato de a escola se fechar para o bairro que a circunda e para os seus habitantes sob a alegação de que deve proteger seus alunos, e de que pouco vale o conhecimento que se dá fora do currículo escolar. É obvio que o conhecimento está no livro e na letra, mas está também no saber que passa pela rua, pelo bairro, pela cidade. A possibilidade de diferentes conhecimentos e diferentes saberes só enriquece a cultura escolar e quando a escola se fecha para a cidade, pouco atenta às imagens e vozes que dela emanam, enviesam-se suas formas de olhar e se limita o sentido do que seja conhecer. É preciso buscar na cidade as cidades. Em um outro lado da face 
conflitante e sombria da metrópole despontam lugares de saber, de esperança e possibilidades. É preciso saber ler a cidade, tarefa difícil, como enfatiza Calvino:

Em Raissa, cidade triste, também corre um fio invisível que, por um instante, liga um ser vivo ao outro e se desfaz, depois volta a se estender entre pontos em movimento desenhando rapidamente novas figuras de modo que a cada segundo a cidade infeliz contém uma cidade feliz que nem mesmo sabe que existe. (1992, p. 135)

\section{NA CIDADE: LEITURAS E NARRAÇÃO}

Historicamente, a cidade surge com a escrita e elas se apresentam intimamente associadas. Como os monumentos, os edifícios públicos e os templos, a escrita é também uma forma de objetivar as relações sociais. $\bigcirc$ texto, uma vez escrito, adquire a mesma materialidade de um edifício, estará sempre onde foi depositado, dispensando, em maior ou menor medida, o seu autor. Entretanto, o texto permanece mudo quando não existe um leitor. Uma cultura não se mantém pela mera preservação de seus textos. Ela só sobrevive quando, geração após geração, a sociedade é capaz de ir formando os leitores para seus textos. Bibliotecas e salas de leitura ganham vida quando abertas e freqüentadas pelo leitor-cidadão.

Babel flutuante, nunca igual a ela mesma, a cidade moderna é uma torrente de signos que carrega o leitor na pressa de seu curso. É o labirinto moderno, atravessado pelo fluir de muitas linguagens que se misturam, se contrapõem ou dialogam no espaço público. Como entende Octavio Paz:

O mundo do homem é o mundo do sentido. O Silêncio mesmo está povoado de signos. Assim a disposição dos edifícios e suas proporções obedecem a uma certa intenção. Não carecem de sentido - pelo contrário - o impulso vertical do gótico, o equilíbrio tenso do templo grego, ou a vegetação erótica que cobre os muros dos santuários de Orissa. Tudo é linguagem. Ou seja, sistemas expressivos dotados de poder significativo e comunicativo. (1998, p.46) 
A cultura, em suas mais diferentes formas de expressão, a educação, a mídia e outros caminhos de acesso ao conhecimento constituem, portanto, um eixo essencial de recuperação da cidadania na luta contra a exclusão e contra a violência. Não se pode esperar participação ativa de um povo ao qual se vedou o acesso ao conhecimento e à educação. Obviamente, vaguear ou precipitar-se pelas ruas da cidade não fará de um citadino um cidadão: é preciso desvendar os seus símbolos, conhecer os meandros de seu tecido, interrogá-la e responder às suas perguntas. De que valerá a cidade, se não se preservarem aqueles que dão voz a seus textos, ou seja, os seus cidadãos? Para Eduardo Portela

Se pensarmos a cidade menos como cidadela, e mais como fonte e núcleo de irradiação cidadã, como tarefa pedagógica de todos e de cada um, talvez possamos avançar um pouco mais. Por enquanto seria precipitado concluir que a educação vem enfrentando, a contento, o desacordo citadino. Porque não basta ensinar na cidade; é preciso ensinar a cidade. (1995, p.8)

Assim, para pensarmos nossas metrópoles em suas relações com a escola, não faz sentido a tentativa de um método acabado, ou uma estratégia de luta. Aprender e ensinar a cidade requerem uma atitude flexível e um movimento de passos em várias direções. Valorizar a cultura e promover a educação é fortalecer a urbanidade que abriga o cidadão. $\bigcirc$ direito à cidade pressupõe a cidade de direito, institutiva da cidadania. Nesse sentido, ler e ensinar a cidade tem aqui o significado de buscar entendê-la como uma construção humana que pode ser falada, escrita, reescrita, escutada, imaginada e projetada, em uma complementação flexível de linguagens e na interação de discursos passados e presentes.

Mas nem tudo são flores na cidade. E não se pode esquecer que a luta de quem vive na megalópole moderna parece recrudescer a cada dia. Contra os atos que focalizam a palavra coletiva e tornam pública a voz do cidadão, assomam mordaças que partem de diferentes lugares. Mordaças que se estreitaram ou se estreitam em incontáveis momentos da história humana. $\bigcirc$ objetivo não é o de apenas cercear a palavra, mas o de bloquear o próprio homem, que se rebela, em suas possíveis ações. Nessas horas, tentar esconder o mais sutil resquício que represente a discordância, talvez seja a alternativa para aque- 
les que, simplesmente, insistam em sobreviver. Mas na contramão dessa tentativa absurda, desvela-se a sobrevida que se faz com a escrita, como expressa, ironicamente, o fragmento do poema de Bertold Brecht (2000, p.59), em referência ao nazismo:

Apague as Pegadas

Separe-se de seus amigos na estação

De manhã vá à cidade com o casaco abotoado

Procure alojamento, e quando seu camarada bater:

Não, oh, não abra a porta

Mas sim

Apague as pegadas!

O que você disser, não diga duas vezes.

Encontrando o seu pensamento em outra pessoa: negue-o.

Quem não escreveu sua assinatura, quem não deixou seu retrato

Quem não estava presente, quem nada falou

Como poderão apanhá-lo?

Apague as pegadas!

(Assim, me foi ensinado)

Não se exponha: apague as pegadas, encontre um disfarce. Mensagem de ironia amarga que parece profetizar o silêncio imposto pela brutalidade e pelo fanatismo. Mas se há tempos que submetem o homem à barbárie que advém da ordem instituída por um Estado que proclama a guerra, ordena a perseguição política, sufoca a palavra, há tempos ainda, que obrigam o citadino a conviver com o medo e a desordem, que escapam pelos dedos das instituições, enfraquecidas para assumir o seu papel de controle da ordem pública.

Presencia-se, nesse caso, a impotência de um Estado que descuida a lei e submete o cidadão à violência dos que vivem "fora da ordem", ameaçando seus passos pela cidade. De formas diferentes, o cidadão se esconde, se aliena e se disfarça. Fecha-se em condomínios e prédios gradeados, cioso de apagar o seu rastro, seja ele simbólico ou material. 
Em um dos muitos trabalhos de Benjamin que dizem a cidade, vale mencionar a leitura que faz do conto de Poe $O$ homem na multidão (1993). Se os transeuntes que antes circulavam pela multidão olhavam em todas as direções sem um objetivo específico, hoje, os pedestres da cidade moderna devem ter o seu olhar disciplinado para seguirem, por exemplo, os sinais de trânsito. Assim, a técnica submeteu os sentidos humanos a um complexo tipo de treinamento; entretanto, a disciplina imposta mal consegue dominar a horda que a própria cidade criou. Horda a que Poe já se refere, quando sugere que haveria algo de bárbaro e de ameaçador na multidão anônima, que peregrina pela cidade do século XIX. Para Benjamin, o magnífico conto de Poe junta à primeira descrição do flâneur a profecia de seu fim.

Considera João do Rio que "flanar" é

...verbo universal sem entrada nos dicionários, que não pertence a nenhuma língua... Para compreender a psicologia da rua não basta gozar-lhe as delícias como se goza o calor do sol e o lirismo do luar. É preciso ter espírito vagabundo, cheio de curiosidades malsãs... é preciso ser aquele que chamamos flâneur e praticar o mais interessante dos esportes - a arte de flanar... É vagabundagem? Talvez. Flanar é a distinção de perambular com inteligência. ( 1997, p.50-51)

Se, na cidade do século XIX, o bazar, as galerias, as passagens são os lugares que ainda restavam ao flâneur, o que dizer da megalópole de nossos dias? Quando olhada de uma forma pessimista, como o homem que é seguido na multidão de Poe, é inútil tentar seguir alguém na cidade de agora, pois o medo anuvia o espetáculo que nela circula, e vem-se perdendo a "alma encantadora da rua", mostrada por João do Rio, no começo do novecentos. Em uma previsão catastrófica, entende-se que a megalópole poderá deter o movimento do cidadão para entorpecê-lo em lugares fechados de onde contemplará em disfarce o espetáculo humano da violência urbana e da exclusão.

Entretanto, sem comungar essa idéia de uma cidade-medusa que, ao deformar a imagem daquele que a contempla, o petrifica pelo horror, presume-se que sempre haverá tempo para que se assegurem espaços e movimentos, nos quais o homem ainda pode estabelecer-se em sua humanidade. E sem ignorar os limites impostos ao cotidiano de seus habitantes, pelos desvios e 
desvarios da megalópole, andar hoje pela multidão é, sim, um risco que exige a prática de ritos e gestos de proteção, mas é preciso procurar e escolher os itinerários passíveis de mostrar, sem tanto pessimismo, a grande cidade de hoje.

É também verdade que nas cidades modernas, vão-se destruindo os lugares de encontro, obstruindo-se as passagens, afastando-se os citadinos. As praças perderam o seu centro, foram-se os dias da ágora, mas ainda é possível encontrar a palavra nos recantos das bibliotecas, dos museus, dos teatros, das escolas, nos versos dos cantadores e no gesto dos benzedores. Lugares em que o homem pode ouvir, falar, contar, rememorar. Por isso, talvez a arte de narrar - que é tão antiga quanto a condição humana - mostre o seu exemplo de prevalência.

A narrativa pode existir como um fenômeno de resistência, ultrapassando tempos, lugares e sociedades, como ocorreu com os trabalhos de Homero, Brecht, Benjamin, Guimarães Rosa, Borges, Montaigne e tantos outros. "Se a narrativa está aí com a vida" (Barthes et al., 1971), retomar e humanizar os espaços dos narradores e da narrativa, sem estreitar saudosismos ou reverenciar o insólito, seria ainda possível?

Assim, ao se estenderem as fronteiras da educação e das escolas, ao se ampliarem as telas de cinema, ao se alargarem as portas dos museus, e dos teatros, na busca de vozes lúcidas que narrem e mostrem suas próprias experiências, talvez se reavive o diálogo entre as diferentes culturas que habitaram e habitam as cidades. Seja nos espaços fechados ou na oratória das ruas, importa o verbo que dá força à vida. Tudo bem se o diálogo estiver mais próximo do agonístico que da harmonia, importa que a cidade se entregue a uma conversa séria, pautada pelas marcas da cultura e pelo encontro com seus cidadãos.

Desde os seus primórdios a narrativa significou tanto um meio de o homem enfrentar dilemas, preservar a sua memória, quanto expressar os seus sonhos e reconhecer, no próprio rastro de sua obra, a sua humanidade. Assim, tentar ampliar e fortalecer o lugar da narrativa, nesses tempos vazios de experiência, poderia ser uma resposta ao cidadão. Longe da melancolia que entorpece a ação, ou do fervor que mascara a realidade, valeria pensar na narrativa - oral e escrita - como formas de devolver ao homem e, muito especialmente, à criança a palavra que vai se perdendo. Para Benjamin, as tantas formas de comunicação modernas se distinguem da narração, que é uma das mais antigas formas de comunicação: 
Esta [a narração] não tem a pretensão de transmitir um acontecimento, pura e simplesmente (como a informação o faz); integra-o à vida do narrador, para passá-lo aos ouvintes como experiência. Nesse ficam impressas as marcas do narrador como os vestígios das mãos do oleiro no vaso de argila. ( I99 I, p. I07)

Pode ser que nas praças da cidade moderna a palavra esteja na boca do migrante, no disfarce do menino de rua, na oferta do ambulante, na promessa do pregador de religião, no silêncio do homem apressado que atravessa o espaço em desatenção, no ritmo frenético do rap. Mas seria essa a palavra de um cidadão, de quem habita e conhece a cidade e tem nela garantidos o seu lugar e a sua palavra? Quem assume o lugar no centro? Haveria ainda um centro? E ainda mais perguntas: que cidade é a cidade de nossos dias? $\bigcirc$ que é ser cidadão hoje?

Tais questões brotam de obras e lugares diversos, o questionamento e o olhar sobre a cidade se espargindo das mais diferentes áreas do conhecimento. Sem a pretensão de fazer um levantamento das obras que investigam a cidade, destacamos alguns estudiosos que focalizam a cidade como um símbolo a ser desvendado. Citamos: Walter Benjamin, Italo Calvino, Michel de Certeau, João do Rio, Raymond Willians, Marc Augé, Rem Koolhaas, Ecléa Bosi, Massimo Canevacci.

Ainda que a literatura seja pródiga em estudos que abordem a cidade sob diferentes perspectivas, não são muitas, em nosso meio, as pesquisas que tratam das relações entre a cidade e a educação. E a respeito desse tema, faz-se importante lembrar o Seminário "Cidade e Educação", promovido pela prefeitura do Rio de Janeiro. A publicação dos textos apresentados no encontro ( 1995 ) revela a preocupação de seus autores em chamar atenção para a importância do estreitamento das relações escola/cidade, num diálogo constante e diverso ${ }^{2}$.

Levando em conta as idéias de autores e estudos que focalizam a cidade, seja em um sentido mais amplo, seja os que enfatizam mais especificamente

2. Neste sentido das relações cidade/escola, o Projeto A Cidade é uma Escola, que tem sido desenvolvido pela Prefeitura do Município de São Paulo, poderá significar uma iniciativa importante para o entendimento da cidade como um espaço que educa, se mantidas as condições materiais e pedagógicas para a realização do trabalho. Evento realizado no Páteo do Colégio em 12/3/2006 com professores da rede municipal torna público o projeto. 
as relações cidade/educação, faz-se importante que a escola compreenda e se prepare para ampliar a sua idéia de cidade. Esta como um espaço que educa e como um texto a ser desvendado; não basta apenas enfatizar o espaço físico e dizer das virtudes e misérias das nossas megalópoles. Para se conhecer e dar concretude à cidade cabe à escola abrir-se para a escuta das muitas vozes e culturas que povoam a urbe.

Nesse diálogo e na polifonia de possíveis interlocutores que contam, recriam, imaginam, fantasiam, exaltam e ou degradam a cidade, certamente se mesclarão condições e modos de viver que poderão revelar características humanas e humanizadoras da megalópole. Que não se percam, portanto, a singularidades e os pontos de encontro nas formas de falar e de ver a cidade, que aqui se mistura com a própria vida. Às profecias do vendedor de ervas, aos trejeitos do menino de rua, à esperança do escolar ou às lembranças dos mais velhos, poderão juntar-se a voz do professor, liberada ou carregada de preconceitos, bem como as falas e as expressões sonhadoras, realistas, amargas, saudosistas de outros narradores.

$\mathrm{Na}$ esteira de estudos e pesquisas que olham a cidade através de seus símbolos e buscam em seus rumores e silêncios, a polifonia de uma história, tenteamos, com passos de quem principia, adentrar os labirintos da cidade. Sem uma perspectiva única, mas em uma pluralidade de entradas, talvez fosse possível engendrar pontos de vista descentrados e apreender nas vozes culturais e nas linguagens que animam o espaço urbano um recado a ser interpretado, especialmente, pela escola e pela educação. Olhando, portanto, em várias direções, foram tomando corpo muitas dúvidas e inquietações. E de início já nos perguntávamos:

- Como contribuir para a ampliação dos horizontes da escola em relação aos bens culturais e artísticos que se fazem presentes nos diferentes espaços da cidade?

- Como ouvir e atribuir significado aos muitos textos e às diferentes vozes que circulam além dos muros escolares e que, uma vez compreendidos, marcarão os sentidos da identidade cultural e da cidadania?

- Como ajudar a escola a se abrir para melhor aprender e ensinar a cidade, atenta ao seu papel social e de mediadora de conhecimento? 
E é dessas perguntas que surgem os estudos, voltados para a questão da cidade, que tenho desenvolvido desde $\left.199\right|^{3}$. Na tentativa de contribuir para a discussão a respeito da cidade moderna, retomo, neste texto fragmentos de algumas dessas pesquisas, situações, cujo objetivo principal foi dar a palavra para diferentes grupos sociais que vivem na cidade.

Abordo, a seguir, quatro desses grupos cujas formas de ver a megalópole dão uma tênue idéia de como alguns de seus habitantes compreendem a cidade. Suas falas foram sintetizadas sob as categorias: "a cidade imaginada", que identifica a visão de pequenos lavradores do Vale do Jequitinhonha sobre a grande cidade; "a cidade olhada de longe", referente à visão de meninos/meninas que vivem no centro de São Paulo; "o desencanto da cidade", que mostra as falas e imagens de alunos de escolas públicas da periferia urbana e "a cidade contestada", como aparece no rap cantado pelo jovem da periferia.

\section{A CIDADE IMAGINADA}

Um excerto da fala de João Porém, como é chamado um dos lavradores que entrevistei no Vale do Jequitinhonha ${ }^{4}$, revela a sua forma insólita de ver a grande cidade:

E eu cá de mim, eu mal sei assiná o meu nome e eu queria saber mais... De leitura queria saber mais, queria... sei só um fiapim... Aqui não tem progresso.

3. Iniciei esses trabalhos no começo dos anos $90 \mathrm{com}$ a pesquisa realizada no Vale do Jequitinhonha, junto a habitantes que viviam na zona rural. A seguir, em 1997, no projeto de pesquisa Professor: Leitor Crítico de sua Prática, subsidiado pelo Conselho Nacional de Desenvolvimento Científico e Tecnológico - CNPq -, o tema da cidade é tratado em um dos projetos didáticos, desenvolvidos por professores participantes da investigação. Com o projeto Lendo na Praça, subsidiado pela Secretaria de Educação do Estado de São Paulo, em 1998, investigamos as aventuras de meninos/meninas que vivem nas ruas paulistanas. Entre 2000 e 2004 desenvolvemos o projeto Leituras da Cidade e Educação, com financiamento do CNPq. Em 2003 abordo a questão da cidade em tese de livre-docência Era uma vez a palavra. E ainda em 2003, São Paulo é vista nos anos iniciais da Primeira República, na dissertação de minha orientanda Maria Cristina Perez Vilas; neste ano a tese de doutorado de Ana Maria Lima Teixeira, por mim orientada, focaliza a São Paulo de 1830- I833. Continuo agora a estudar a cidade com o projeto A Infância na Cidade Moderna.

4. Sobre a pesquisa, ver o trabalho: Dietzsch (1995); o "porém" que pode parecer sobrenome de João Porém, é só um apelido. Segundo os amigos é porque João tem a mania de botar "porém" em tudo. Trata-se de um João adversativo. 
Não tem causa que o governo, certeza que o governo, num ainda tomou parte pra fazer o progresso que é preciso. Os pastos lá vai entrando, os véio lá vai acabando, os novo vai indo embora... Antes quase todo mundo era uma alegria, mais entristeceu tudo... Eu mesmo queria é ir antá eles... romper... ir me embora. Antá eles lá na cidade. Lá a gente planta o que quer, a terra é de bastante. É tudo plantação... tudo verde. Magino que Belo Horizonte é tudo plantação. Cada um planta um meio prato, uma medida e arreúne tudo. Tudo reunido, sem reparo, sem candonga... o conforto num tinha que vim de longe. Certo que os tempo parava de entristecer... (Reconstrução da fala de João Porém)

Uma cidade onde tudo é plantação e que vai satisfazer o desejo de quem busca o direito da sobrevivência. E para realizar esse desejo, mais um sonho, o de ter a leitura e romper para a cidade. Inscrito nesses dois anseios, talvez um outro, o qual João Porém nem mesmo saiba verbalizar: o de ser um cidadão. Ser alguém que não apenas sonha com a terra de bastante, mas que por direito poderá plantar e partilhar com outros plantadores o sustento e o conforto de quem pode colher o fruto de seu trabalho. A fantasia de uma cidade onde tudo é plantação!... De onde vem a imagem desse sonhador? Isolados em um sítio o "Boa Esperança", João e seus vizinhos adivinham um mundo e nele arquitetam um espaço com a mágica e o formato de seu sonho. Distantes da tecnologia, o ambiente físico e a natureza são fortes suportes de sua visão de mundo.

Em países subdesenvolvidos, como o nosso, onde o rural, mais primitivo, e o industrial e a tecnologia mais moderna coexistem sem se comunicar, o desconhecimento e a representação que João faz do urbano podem parecer estranhos, mas não absurdos. Enraizadas em um passado distante, suas imagens parecem reviver com aquelas de uma cidade medieval onde nada era separado, as trocas e a produção se abrindo para as ruas: vias naturais de passagem para a casa e para o campo.

Abstraindo-se do que vive, essa gente teimosa sonha com uma terra esperança, enquanto pisa uma terra ocupada: batida pelo gado, entorpecida pelo capim, sugada pelo eucalipto. Nessas esperanças quase alucinadas, o governo, mais que fada madrinha, é a figura que pode derrubar os fortes e trazer a salvação. É o Estado-Pai, protetor dos oprimidos, competente para botar ordem, para corrigir o espaço, dando força ao tempo que vai fugindo de seus 
ciclos naturais. Como antes, não basta mais pedir a Deus que aplaque a natureza com a invocação das rezas e penitências, mais que a seca, são agora os tratores e os pastos que precisam ser enfrentados. Ao alheamento do divino se junta a abstração do Estado, o agrário se mesclando com ordens de outros lugares e de outros sistemas de produção.

Em sua fantasia benfazeja, João adversa a realidade e só conhece as vantagens de um lugar diferente onde vão se cumprir suas aspirações. Não se dá conta da lógica urbana que separa e fragmenta a vida dos citadinos, impondo ao tempo e ao espaço novas formas de organização. Em suas imagens não se afigura a imagem do Estado que, longe de proteger, se apodera do espaço e o rateia, instaurando as desigualdades. Uma vez predisposta em espaços diferenciados, criam-se na cidade as faixas dos excluídos e em nome da harmonia e do direito institui-se o controle dos sinais, das placas de advertência e de outros mecanismos de burocracia e coerção.

Da cidade, João Porém desenha as promessas, mas nada garante, na imagem criada, que possa ser as sombras de seu rascunho. Assim, João quer juntar à liberdade de plantar e dividir, o preparo para responder às perguntas que a cidade vai lhe fazer. Quer-se paramentar segundo seus usos para não ser confundido com qualquer forasteiro menos inteligente. Aliás, a falta de uma escola próxima e a desimportância que o governo e os mais velhos deram ao ensino integram o reclamo de outros entrevistados.

João Porém quer vencer a esfinge e para enfrentá-la busca na leitura seu passaporte. A intuição ou um saber adquirido em conversas e correspondência com quem vive na cidade perpassam a fala de outros entrevistados, como no caso de Manezinho Violero, apoiado por Zé de Ritinha, quando diz: "Se até quem veve no mato faz falta a leitura, no comércio quem não lê não tem progresso. Só tocar, cantar num chega; lá as coisas deferencia...". Retomam assim, a antiga polêmica de oposição campo/cidade, põem em dúvida o seu saber. Vislumbram a leitura como um rito de passagem, como uma prova que, vencida, facilita a travessia.

Chama ainda a atenção o uso da expressão "comércio", em referência à cidade, como aparece em muitas das entrevistas que realizei com os 13 informantes, todos analfabetos, com idade variando entre 14 e 82 anos - conforme consta da certidão de batismo, ou do "batistel", na expressão do grupo. A cidade é o lugar das trocas, dos negócios. Existe mesmo um lugarzinho cha- 
mado Comercinho do Bruno, lá bem no norte de Minas. A cidade nasce com uma vendinha onde paravam os tropeiros e os mascates, e nos pequenos armazéns, nos quais podem se criar os reféns de donos de terra, que pagam seus "agregados" com mantimentos.

No "burgo que João Porém pintou de verde" - metáfora da esperança -, a cidade imaginada de tantos migrantes! Gente que depois pode ter-se perdido na megalópole; se misturado aos camelôs e a outros profissionais da rua; ou que conseguiu sair-se bem na cidade, sonhando em voltar um dia. E, se rompendo a fantasia, João, como tantos outros joãos, pisasse de verdade em uma de nossas megalópoles? Como imaginar o seu destino, se a sociedade urbana, como um labirinto, pode-se abrir em diferentes caminhos ou encerrar civilizados minotauros?

Poderia João Porém emblematizar alguns de nossos migrantes que encontram na praça o lugar de sua luta pela sobrevivência? Mas quem the daria, ou ouviria a sua palavra? Em nome de quem, com que direito falaria João Porém? Ele, que a qualquer momento, como outros joãos, poderia ser expulso da praça onde nada mais representaria que um incursionista, dos muitos que vêm perturbar a cidade?

A cidade imaginada pelos agricultores - que não têm onde plantar - é o lugar da esperança, da escrita, das trocas e da igualdade, mas que também exige de seus habitantes algum preparo. Entretanto, se voltarmos às muitas cidades que compõem a megalópole, não seria fácil identificar, de pronto, a que está nos sonhos do João Adversativo e de seus vizinhos. Não Ihes faltam palavras, imaginação, vontade, apesar da dureza de suas vidas. Talvez a questão não seja de faltas, mas a de uma esperança, que já não existe, para muitos dos que labutam nas megacidades. Como propõe Maria M. Campos ( 1995), se o saber pudesse ir além do regional para se inscrever no espaço territorial: Será "que os tempos parava de entristecer?".

\section{A CIDADE OLHADA DE LONGE}

As praças de algumas de nossas metrópoles são um retrato acabado de faixas excluídas, onde mendigos, loucos e marginais se misturam à multidão, em constante ameaça. Crianças em bandos ziguezagueam na massa, para encontrar o seu lugar. Transitam na planta baixa da cidade e sem levantarem os 
olhos, os meninos e as meninas que vivem nas ruas da cidade aprendem a ler passos e pés. Distinguem a crueldade do coturno e dele se escondem. Seguem o ritmo das sandálias dos sanfoneiros e com eles dançam. Identificam-se com os pés descalços que passam voando e vêem neles um sinal de alerta. Acertam seus passos pelos pés dos grevistas e os acompanham em passeatas. Espreitam os passantes desavisados e com segurança adivinham os seus bolsos.

Inscrita no corpo desses habitantes indesejados, uma história a ser contada, recriada, escrita e mostrada nos diferentes planos da cidade - espaço que, aliás, deveria ser oferecido a todo cidadão. Assim, vistos de corpo inteiro, talvez pudessem olhar para o alto, tendo a chance de enxergar a cidade em suas mais diferentes dimensões. Então, mais do que escorraçados leitores de passos, levantariam os olhos e aprenderiam a escrita da cidade na leitura das linguagens que se permitem ao cidadão.

Com essa idéia de abrir caminhos, nem que ainda tímidos, para a narração tentamos dar a palavra aos meninos/meninas que vivem assombradas aventuras pelas ruas de São Paulo. Com o projeto Lendo na Praça ${ }^{5}$, um ônibus foi transformado em uma sala de leitura e permanecia todo o dia no Largo do Arouche, à espera de seus inusitados leitores. Em um desses dias, a monitora que acompanhava os leitores no ônibus ouviu de um deles o seguinte desafio: "Você sabe ler de perto tia: olha no livro./Eu sei ver de longe. Enxergo tudo na rua".

Os meninos/meninas, que tiram de suas viagens pela cidade a matéria de seu relato, são narradores de uma aventura muito complexa, mas pouco apreciada. Como será realmente o seu tempo, até onde vão suas viagens, a quem servirão os seus conselhos tirados da experiência marginal vivida nas ruas, perguntávamo-nos. Capturados em um mundo de saídas limitadas, os meninos de rua inventam portas e desenham corredores. Constroem nos caminhos urbanizados uma rede invisível que adentra o submundo, para protegê-los das instituições e diferenciá-los do cidadão que pode escolher seus caminhos pela cidade.

5. Considerando-se todos que vieram buscar no ônibus a leitura, ao longo de nosso trabalho, foi possível contar, aproximadamente, 53 leitores que apareciam em dias diferentes. Mais informações a respeito do projeto Lendo na Praça, ver o texto de Dietzsch ( 1998a). 
$\mathrm{Na}$ busca dessas passagens, quase sempre escorregadiças e traiçoeiras, os meninos/meninas aprendem a olhar ao longe e a vislumbrar vultos que se disfarçam na multidão. Desenvolvem um saber que começa na rua, mediado pela astúcia e pelo ardil, que dão agilidade ao corpo, alongam e intensificam os sentidos. Se em cada esquina paira uma ameaça, piscar, parar, ou escorregar são gestos de fatalidade. Quem vive no desvio tem de estar sempre de prontidão. Prontidão para a vida, para o ataque, para a morte.

Assim nos ensinaram os meninos que vinham buscar no ônibus do Largo do Arouche a leitura. Além de nos indicarem algumas regras de seu trânsito pela cidade, de falarem dos efeitos da droga, os meninos e as meninas muito mais nos contaram e ensinaram. E foi em uma dessas conversas que um dos leitores iniciantes disse para a monitora que ela sabia ler de perto e ele lia ao longe: um olhar de rua. E na continuidade de sua fala, vai pontuando seus lances quotidianos em um relato que se desfia em sentimentos, repete-se nas experiências de fuga e assombra com suas imagens de morte e desvarios.

No orgulho de suas façanhas, o desejo, o sonho e a obstinação intercalam a fala do narrador: um menino franzino, de olhos muito vivos e fala fácil. Segundo ele, quem vê ao longe enxerga mais e transforma a rua em um texto menos propício ao sobressalto. Uma leitura capaz de vencer a distância, para vasculhar cantos que podem camuflar fantasmas, ou escudar tipos mal queridos. É assim: quem sobrevive na rua tem de saber olhar, ver de longe, materializar o espaço.

Viajar com o olhar e percorrer espaços, criando artimanhas para enfrentálo... Parecia estar aí a força da leitura para o menino, pois nela, que exige olhos prevenidos e alongados, poderiam estar as regras da sobrevivência e do enfrentamento que não se rendem ao improviso. Ainda que leitor iniciante de outras linhas e cenas menos perigosas que as de seu dia-a-dia, ele sugeria prescindir da leitura do livro, ou entendê-la apenas como um jogo inocente que desconhece a fatalidade, exige pouco e pouco oferece ao leitor.

Assim, lendo de perto fomos descobrindo a força de quem lê ao longe para dominar o espaço e sobreviver na megalópole. Força que, para além da fala, pode se manifestar no semblante de quem ouve com paciência, no gesto de solidariedade, na expressão de quem sonha, na feição desesperada, nos movimentos que transgridem e ameaçam. Na tentativa de entender a leitura distante, propusemo-nos a uma leitura de perto que, reescrita, nos permitisse 
ver mais longe para alcançar uma história feita de vidas, que começam e podem terminar a qualquer hora nos espaços dessa moderna Babel.

De alguma forma, as crianças e os jovens que encontram nas ruas e no centro de São Paulo o seu habitat, têm algo em comum com a dialética da flânerie, dos escritos benjaminianos. De um lado, os meninos se sentem olhados por tudo e por todos; é, simplesmente o suspeito; de outro, é totalmente o insondável, o escondido. Se provavelmente é essa a dialética que o homem da multidão desenvolve, tal sentimento dual, controvertido, parece ainda mais intenso no vaguear ora atrevido, ora sorrateiro dos meninos de rua.

A leitura que os meninos/meninas fazem da cidade confunde-se com a sua própria vida. Falam a cidade; no centro do desvario e com um pleno domínio do seu espaço percorrem-no de muitas maneiras e com sabedoria. Se as ruas são a sua casa preparam-se para defendê-las e disputá-las, palmo a palmo, com a polícia que os persegue, com o incauto que as percorre distraído, com os projetos que pretendem impor-lhes uma ordem. Em seus itinerários de pressa e desconfiança tentam tirar do caminho quem os atravessa. E é com um certo humor amargo que zombam dos "arrastões" policiais que querem acabar com muitos de uma só vez; contam ousadamente de seus furtos, ou melhor, de objetos que "tiraram" de alguém; se vangloriam de poderem escolher a comida que lhes será fornecida em cada um dos "projetos" beneficientes. Na lógica da rua há meandros a serem cursados.

Sem a intenção de "salvar" ou recuperar os meninos/meninas que vivem nas ruas paulistanas, vítimas de uma problemática econômico-social que gera e encaminha suas condições de vida, o projeto Lendo na Praça, sem moralismos, baseou-se na idéia de que a leitura e a escrita, em situação planejada, poderiam introduzi-los em outros mundos e, quem sabe, oferecer-lhes novos modos de ver. Causou-nos, portanto, surpresa, logo no início da pesquisa, a fala de um dos meninos: "Você não quer que eu conte minha vida, tia? Isso aqui não é projeto? Nos outros projetos a gente sempre conta a nossa vida".

Não estava em nossos propósitos que os meninos falassem de sua vida, melhor dizendo, da que eles inventavam em cada esquina, em cada projeto, valendo-se da tragédia criada, para provocar sentimentos de piedade ou chocar o ouvinte. Propusemo-Ihes, no entanto, que nos falassem da escola e ouvimos com atenção os seus relatos. Um dado comum é o de que a escrita e a leitura foram sempre um motivo para o afastamento da escola. Além disso, um 
livro rasgado, a falta de dinheiro para comprar cadernos ou a grosseria de certas professoras foram também motivos arrolados para deixar as salas de aula.

Apesar dos problemas com a escola, mencionados por muitos, alguns dos freqüentadores do ônibus relatam as boas lembranças de momentos vividos na escola, de colegas amigos de brincadeiras, do lanche no recreio e de professoras queridas que os acompanharam nos estudos. Como na fala: "A professora Elisa era morena, assim nem baixinha, nem muito alta nem muito baixa. Era boa, tinha paciência e eu tenho saudades dela", rememora um de nossos leitores. "Eu gostava do recreio e da merenda e das brincadeiras", diz um outro, e ainda: "Se eu soubesse ler, arranjava um emprego".

Existe entre os meninos/meninas de rua uma relação de companheirismo a ponto de mais de uma vez se dizerem e se tratarem como irmãos, o que, obviamente, não significa a inexistência de rixas e desavenças, principalmente, quando a disputa envolve a droga. Muitos se sentem mais protegidos nas ruas do que na família que deixaram, e se orgulham de viverem "livremente", conforme padrões da rua. Não importam os perigos a que estão expostos, confiam em sua agilidade e esperteza para se desvencilharem das armadilhas e desencontros com o inesperado. Conhecem a senha que permite o trânsito pelos labirintos da megalópole e a utilizam sem qualquer escrúpulo. Essa é a regra da sobrevivência de quem fez da rua o seu "lar".

Na fala do menino que "lê ao longe", está implícita a idéia de que para se ultrapassar as fronteiras das diferentes cidades que constituem a megalópole, há a exigência de senhas e códigos, cujo desconhecimento pode significar embustes e falências. Qual uma esfinge impiedosa, a megalópole devora cidades e caminhantes que, sem entender os seus desníveis, vacilam ao responder às suas traiçoeiras questões. Entretanto, devorar seria pouco se desse processo não resultasse uma multidão adoecida por estranhas ou desumanas alucinações.

No enfrentamento dessa multidão da qual os meninos são, contraditoriamente, vítimas e algozes, não parece haver espaço para a esperança e idealismo inocentes da cidade imaginada por João Porém. Entretanto, é possível falar positivamente da leitura feita da cidade, por alguns desses aventureiros da rua. Tal interpretação humanizada não era rara entre os leitores que encontravam nos livros, nas histórias ouvidas, na leitura do jornal e nas conversas que aconteciam no ônibus, um prazer descuidado, sem reticências. A fala de um deles merece atenção: 
Eu adoro morar na rua, aqui tenho amigos, meus irmãos, e não tenho nada que me prende. Se na praça não tivesse os polícias que atacam até os "mocós" eu não queria nada mais. A gente não gosta de roubar, de matar à toa. É a polícia e a "nóia" é que faz isso.

Aos olhos dos meninos de rua, a cidade pode não ter uma cor, não é a cidade verde dos lavradores do vale, mas é o lugar do arrebatamento, da liberdade e libertação, do livre circuito, para quem aprendeu a ler ao longe.

\section{O DESENCANTO DA CIDADE OU A CIDADE DOS DESEJOS?}

Diferentemente dos meninos/meninas que vagueiam pelas ruas de São Paulo, os que vivem com seus familiares e freqüentam escolas públicas, distantes do centro, pouco sabem das muitas cidades que existem para além de seu bairro. Suas experiências, quase sempre, se limitam ao lugar em que vivem. No entanto, ainda que mal conheçam lugares que constituem uma amostra privilegiada da cidade, o desafeto e o medo mesclam as imagens da megalópole distante, que lhes chegam distorcidas, pelo sensacionalismo dos programas de TV, das histórias contadas, das figuras de alguma revista. Dados de investigações - Professor Leitor Crítico de sua Prática (1998) e Leituras da Cidade e Educação (2000-2002) ${ }^{6}$ - revelam a representação negativa dos alunos entrevistados em relação a São Paulo.

Tal visão da cidade chegou-nos pelo projeto didático, A Criança e a $\mathrm{Ci}$ dade de São Paulo, realizado pelas docentes participantes das pesquisas que desenvolvemos em 1998, 2000-20027. Para ouvirmos as crianças falarem da cidade, escrevemos junto com as professoras uma pequena carta, que chegou

6. No projeto Professor: Leitor Crítico de sua Prática, além da proposta com a leitura e a escrita por mim coordenada, a Prof. Dra. Marli André organizou o seu trabalho tendo como ponto de partida as concepções e a práticas de avaliação em sala de aula de professoras da rede pública estadual. O projeto Leituras da Cidade e Educação, sob minha coordenação, surgiu de questões oriundas de "Professor: Leitor Crítico..." com o objetivo de proceder à leitura das muitas cidades que compõem a megacidade paulistana.

7. A respeito do trabalho com os professores na Universidade de São Paulo - USP -, consultar o texto de Dietzsch (2004). 
às mãos dos alunos por seu intermédio. Anexamos à correspondência cinco cartões postais referentes ao Parque Ibirapuera, Páteo do Colégio, Avenida Paulista, Estádio do Pacaembu e Museu do Ipiranga, Palácio Bandeirantes e pedimos às crianças que nos dessem sua opinião para as seguintes perguntas:

I. Vocês já estiveram nesses lugares ou já os conhecem pela televisão, de revistas, ou de outras fotos?

2. Que outros locais de São Paulo gostariam de conhecer?

3. Se pudessem escolher outro nome para São Paulo, que nome escoIheriam?

4. O que você mais gosta no seu bairro?

5. Se você fosse prefeito da cidade, o que faria para São Paulo?

6. Você acha que São Paulo é uma "Cidade Esperança"?

Em resposta às nossas perguntas, recebemos cartas de 374 alunos, procedentes de 16 escolas, 14 situadas em bairros distantes do centro. A correspondência que já vínhamos utilizando para o contato com os alunos continuou a incentivar e movimentar o trabalho nas salas de aula e na escola de modo geral. As professoras chegavam para os encontros na USP, carregadas com um rico e inteligente material produzido pelas crianças $^{8}$.

Do total de respostas recebidas, em cartas individuais ou em grupo, $26 \%$ indicavam que os entrevistados não conheciam qualquer dos lugares mostrados nos cartões e nunca tinham vindo à cidade, mas $5 \%$ já haviam visto alguns desses lugares na TV. Em uma das cartas, o remetente diz: "Para falar a verdade, nunca cheguei a conhecer esses lugares, mais bonitos"; outro promete: "Nunca fui. Quando eu tiver I 8 anos vou poder ir". Quando a questão versa sobre os lugares que gostariam de conhecer em São Paulo, o Play Center prevalece como o mais desejado, somando 9\% das respostas. Segue o Parque do Gugu com 6\% das respostas. Na lista, aparecem ainda o Pacaembu, Museus do Ipiranga, MAM e do Monet, como lugares de interesse para serem visitados.

8. A bolsista de Iniciação Científica, Roseane Batista de Sousa, trabalhou intensamente conosco nesse momento da pesquisa, sua colaboração sendo de grande importância para a organização e apresentação dos dados coletados. 
$\mathrm{Na}$ continuidade, as respostas se dispersam por diferentes lugares que os alunos gostariam de conhecer. Na ordem de preferência estão: o Parque da Mônica, Beto Carreiro, Butantã, Horto Florestal, Simba Safári, a USP - provavelmente por influência das professoras e de nossa correspondência com as escolas. Algumas respostas soltas que indicam o anseio dos alunos em conhecer lugares que não se situam em São Paulo, como: o Pão de Açúcar, as Pirâmides, o Maracanã, sugerem mais um desconhecimento da cidade do que o não-entendimento das questões, sobejamente explicadas em classe.

Quando propusemos que os nossos correspondentes assumissem o lugar do prefeito, esses meninos/meninas que margeiam a vida paulistana revelam como gostariam de fazer algo para uma cidade que lhes assusta como um espaço de carências: faltam moradias, hospitais, transportes, higiene, educação. Apesar da diferenciação das respostas, há nelas um apelo, ou a busca de alguém que se preocupe com a pobreza, a violência, especialmente contra as crianças, com desemprego, com os moradores de rua, com a falta de transporte, com a agressão ao meio ambiente e a poluição. Os temas abordados poderiam ser reunidos em categorias como: "miséria", "trânsito", "violência", "economia”, "infra-estrutura”, "educação", "saúde”, "poluição”, "drogas”, "governo".

Ainda que não haja espaço para a transcrição das respostas obtidas, vale mencionar algumas que podem dar uma idéia mais clara de como a cidade é lida pelos alunos.

Se eu fosse prefeito não roubava e fazia um obra de 22 mil casas para todos os desabrigados de São Paulo; Eu aumentava a mesada de todas as crianças e não deixava que elas fossem maltratadas; Os presos eu mandava matar e aí ia diminuir os bandidos; Eu acabava com o desemprego. A maioria das pessoas estão desempregadas. E assim fica difícil para as famílias das crianças colocarem alimentos dentro de casa. E começa a aumentar os mendigos e eles começam a roubar, e o desemprego se transformam numa tragédia; Eu mandava plantar árvores nas ruas e os carros não poluir mais; Precisa acabar com a violência, com os assaltos. A violência é mau exemplo para as crianças que viram trombadinhas. 
A recorrência de temas referentes às dificuldades enfrentadas no espaço urbano revelam a visão desencantada que essas crianças da periferia têm da cidade de São Paulo. Falam muito pouco do bairro e quando mencionam os lugares de que mais gostam referem-se aos espaços de brinquedos, às pracinhas. Nenhuma resposta a respeito da escola.

Francesco Tonucci, em seu livro La ciudad de los niños (1996), diz que há muito tempo tínhamos medo do lobo do bosque. Era o bosque do lobo, do ogro, da escuridão. O lugar pelo qual era possível se perder, ser devorado pelas feras ou morto em mãos de feiticeiras. Esse é o tempo dos contos infantis, que ainda fazem parte da vida de muitas crianças. Mas para outras, como as que entrevistamos, a cidade é que parece ser a selva, habitat do lobo, lugar da escuridão. Nessa selva social acontecem as mais diversas violências: é o espaço do desemprego, dos assaltos, sequestros, da miséria, das discriminações.

No entanto, surpreendem as palavras de esperança despontadas nas falas das crianças quando Ihes é sugerido que proponham alternativas para a humanização da Paulicéia. Em imaginação, como no caso da pergunta se seria São Paulo uma "Cidade Esperança" ou quando lhes pedimos que escolhessem um outro nome para São Paulo, causa impressão a criatividade e o cuidado de pensar e inventar nomes para São Paulo: "Cidade do Sonho", "País do Sol", "Cidade Altar", "Cidade Paraíso", "Mundo da Magia", "Nova Esperança", " Cidade Alegre", "Cidade Feliz", "Alecrim Dourado", "Cidade Maravilhosa", "Água Brilhante", "Dragão de Aço".

Parece que falam de uma outra cidade, uma "cidade dos desejos" que gostariam de alcançar, para "passar a limpo" a megalópole de que fazem parte, especialmente, para os que não participam dos bens culturais e materiais que constituem, para muitos, uma face desconhecida da megalópole.

Sob o impacto da representação de São Paulo contida nas respostas dos alunos, planejamos com as professoras a continuidade do projeto sobre a cidade. Mapas foram estudados, explorados postais, discutidos pequenos textos e poemas que falam de cidades. As crianças falaram, escreveram e desenharam suas impressões e imagens a respeito da cidade. E ainda em resposta às nossas cartas continuaram a chegar textos escritos, painéis, desenhos e colagens, retratando espaços, pessoas e problemas da cidade. Alguns desses 
desenhos e painéis são preciosos pela força da sua palavra e beleza simples de suas imagens ${ }^{9}$.

Os dados coletados trazem informações importantes a respeito das noções e imagens que crianças da periferia urbana têm de São Paulo. Indicam ainda a importância de passear com os alunos pelos de seus desejos, mostrando-Ihes imagens, objetos, textos literários, filmes que falem e revelem os diferentes espaços da megalópole. $\bigcirc$ trabalho desenvolvido pelas professoras em classes teve a importância de aproximá-las de uma cidade que Ihes era também pouco conhecida, principalmente como um espaço da cultura, de aprendizagem e conhecimento. A escola poderá se abrir e encontrar respostas na cidade quando nela se fizer ouvir a voz do urbanista, do museólogo, do poeta, do migrante, do velho, do menino de rua, a mostrar-lhes muitas faces da megalópole.

\section{A CIDADE CONTESTADA}

A palavra desencantada de meninos/meninas que vivem hoje afastados do centro urbano pode muito bem aparecer amanhã em textos e músicas que falam de uma cidade, sombreada pela desigualdade e pela pobreza que margeiam as megalópoles. Pensando nas condições de existência que marcam a vida na metrópole, condições capazes de incentivar e produzir sentimentos diversos, as letras de rap são formas diferentes de ler e de expressar a cidade. Nas músicas cantadas pelo jovem da periferia urbana, a cidade é mostrada em um movimento de protesto que congrega a expressão de um grupo sociocultural que se sente discriminado e injustiçado ${ }^{10}$.

A origem do rap remonta à Jamaica dos anos 60, por meio dos "sons" colocados nas ruas dos guetos jamaicanos para animar bailes que serviam de fundo para o discurso sobre a violência das favelas e a situação política da ilha,

9. Considerando o valor do material, fotografamos parte dessa produção, conservamos alguns cartazes, que ainda continuam arquivados conosco.

10. O conhecimento do rap teve a contribuição incansável e inteligente da bolsista de Iniciação Científica Flavia Jabur Rodrigues. Para melhor entender o movimento Flávia foi além do que planejávamos em nossos encontros de orientação: participou de encontros e outros eventos, conversou com jovens ligados ao rap, ouviu e gravou letras das composições, consultou a bibliografia que trata do tema. 
além de temas mais prosaicos, como sexo e drogas. Na década de 70, com a crise social que abateu sobre a ilha, muitos jovens emigram para os Estados Unidos e introduzem em Nova York a tradição do canto falado - rap - que fazia parte do hip-hop.

Estabelecido por volta de 1968, o termo hip-hop foi inspirado em duas movimentações cíclicas; a primeira estava na forma de transmitir a cultura dos guetos norte-americanos e a segunda estava justamente na forma de dançar, mais popular da época, ou seja saltar (hop), movimentando os quadris (hip). Para se expressar, o hip-hop apropria-se das ruas, como um movimento sociocultural, relacionado com o espaço-cidade que é ocupado pelos jovens da periferia em seu dia-a-dia e que revela sua visão da metrópole.

O break, uma dança inventada pelos porto-riquenhos, veicula a insatisfação com a política e a guerra do Vietnã. Em suas performances imitavam helicópteros de guerra, ou até os soldados que voltavam mutilados. A nova dança alastrou-se com as gangues nova-iorquinas que respondiam com violência à opressão social e tinham na forma livre e no apelo visual do break a possibilidade de chamar a atenção das massas. Os movimentos intrincados, acrobáticos, mas altamente plásticos e harmônicos da dança começaram a se expandir, trazendo com ela o graffitti, de colorida expressão visual e o rap, a trilha sonora que completava o cenário.

Os rappers surgem na vida paulistana nos anos 90, não apenas como grupos musicais no sentido estrito, mas integrados a um movimento estéticopolítico mais amplo: o hip-hop. Experiências inicialmente desenvolvidas no centro urbano, mais precisamente, no espaço da Estação São Bento, marcam a cultura de rua e se estendem para integrar-se depois ao Geledés'", ao mercado fonográfico alternativo e ganhar a periferia (Andrade, 1999).

As letras dos rappers procuram passar a realidade da exclusão social, do preconceito racial, das drogas, da política, da diferenciação de classes e da péssima condição de vida nas periferias da cidade. Denunciam o sistema opressor que patrocina a miséria, fatalmente ligada às mazelas que assolam o cotidiano das periferias no Brasil. A denúncia veiculada pelo discurso do rap se estabelece com a delimitação "do lugar de quem fala, de onde fala, para quem fala". A palavra é

I I. Geledés: instituição de defesa da mulher negra. 
mais agressiva, se dirigida ao governo, à polícia, e é mais moderada se dirigida aos moradores da cidade. A música Fim de semana no parque - autoria do MC's é dirigida à comunidade da zona sul, enquanto a música Brasil sem educação, do grupo Face da Morte, dirige a palavra ao ministro.

Aí Ministro/Sou porta voz desse povo faminto/ Meu povo sofre se lembre disso [...] Já que sou bandido/ De Educação eu preciso/ Aí Ministro da Educação/ O futuro da Nação/Vai à escola só pela refeição/ Que às vezes não tem o suficiente/ Pra repetir o prato...

Ao transmitir uma realidade política e social que marca a vida da metrópole, as letras do rap oferecem possibilidades para a leitura da cidade de uma perspectiva ainda pouco explorada, a do jovem negro da periferia: é a cidade vista do avesso. "Esse lugar é um pesadelo periférico/Fica no pico numérico da população./ De dia a pivetada a caminho da escola/enquanto à noite os mano decola na farinha... Na pedra... usando droga de monte... " (Edy Rock).

No afã de dar o seu grito de protesto, jovens tentam se libertar dos espaços que o excluem pelo ritmo frenético que acompanha a fala-cantada que mais desdiz do que canta a cidade. Ainda que a leitura do espaço urbano esteja, quase sempre, enraizada nos problemas da periferia, ampliam-se com palavra os espaços de indignação. A cidade, vista pelo rap, é o lugar de alguns que são ridicularizados por seus hábitos, suas condições de vida, por seus bens materiais. A megalópole se divide em dois mundos antagônicos. Nos bairros ajardinados e condomínios, se encastelam os privilegiados. Nas favelas, e periferias, vivem os pobres seus insondáveis problemas, desconsiderados ou banalizados pela sociedade.

O rap Fim de semana no parque traz à vista essas duas cidades, objeto da crítica, da força e determinação, vestidas com a ironia de quem conhece bem a vida da periferia. $\bigcirc$ fragmento a seguir desse texto, recorta em pedaços a cidade para expor a olhos e ouvidos uma de suas mais sombrias faces:

As garagens abertas eles lavam os carros/ desperdiçam a água eles fazem a festa/ Coroa rico boca aberta a isca predileta./ Sou assim e estou legal até me leve a $\mathrm{mal} / \mathrm{malicioso}$ e realista sou eu mano brown/ me dê quatro bons motivos pra 
não ser/ olha meu povo nas favelas e vai perceber/ Daqui eu vejo uma caranga do ano/ toda equipada e um tiozinho guiando/ com seus filhos ao lado estão indo ao parque/ eufóricos brinquedos eletrônicos/automaticamente imagino/ a molecada lá da área como é que tá/ provavelmente correndo para lá e pra cá/ jogando bola descalços nas ruas de terra/ e brincam do jeito que dá/ gritando palavrão é o jeito deles/ eles não tem videogame às vezes nem televisão/ mas todos eles têm em São Cosme e Damião/ a única proteção. No último Natal, Papai Noel escondeu um brinquedo/ prateado brilhava no meio do mato/ um menininho de 10 achou o presente/ era de ferro com 12 balas no pente/ e o fim do ano foi melhor pra muita gente/ eles também gostariam de ter bicicletas/ de ver seu pai fazendo cooper tipo um atleta/ gostam de ir ao parque e se divertir/ e que alguém os ensinasse a dirigir...

A esfinge é enfrentada por manifestações culturais que refletem a tensão entre cidades antagônicas. É o mundo da violência policial e de outras instituições que deveriam cuidar e não hostilizar o cidadão, como nos versos a seguir:

O Carandiru está de casa cheia/ Muita maldade no ar muita droga na areia/ Se quiser ver é só virar a esquina/ Os irmãozinhos se matando pela heroína é incrível como isso pode acontecer/ Bem no meio da cidade não dá pra ver/ Falam que aqui estão nos reeducando/ Mas é mentira, na verdade estão é nos marginalizando [...] E que loucura a blitz do choque/ Eles todos armados, cachorros pra todo lado/ E eu ali pelado no meio do esquadrão/ Com medo dos cachorros morderem os meus grãos...

Palavras como esquina, depósito de luxo, demarcam a relação excludente da megacidade para com uma imensa parcela de seus habitantes que acabam sendo educados para a marginalidade. Se os autores do rap fazem pouco uso de subterfúgios e mediações, exploram uma linguagem oralizada, direta, cheia de gírias e expressões típicas da periferia. Desfecham sua braveza pela ironia agressiva e reafirmação de seu desprezo. Mas no espaço de autonomia e identidade criado, a palavra cantada com seu ritmo acelerado, quebrado e forte, gera força para discutir posicionamentos e opiniões sob uma perspectiva que 
denuncia, dura e cruamente, as veias por onde correm as mazelas das megacidades $^{12}$. Parece que os rappers cantam em nome dos meninos de rua.

\section{E A ESCOLA SE ABRE PARA A CIDADE}

Ler e ouvir as cidades que se ocultam na megalópole. Essa leitura-escuta da cidade pode começar nos espaços da memória, nas ruas e praças, nos morros ou nas salas da escola, para depois de analisada e revigorada, no contato com as vozes que dela emanam e com os bens culturais e artísticos, voltar à escola na forma de pontos de vista, de visões diferentes e diferenciadas. Daí poderá circular em lugares diversos, humanizada pelo conhecimento e pela sensibilidade. Utopicamente, poderemos pensar em habitantes mais preocupados com a cidade, como um lugar de sua existência e não somente como o lugar dos outros violentos e usurpadores. A cidade pode ser aprendida e ensinada.

Para Maria Malta Campos, novas formas de comunicação devem ser buscadas no relacionamento entre a escola e o bairro, entre o que está dentro e fora dos muros escolares, e o papel da escola deve ser repensado como centro organizador de experiências e aprendizagens que se dão fora de seus limites, com o empenho de: professores, famílias, e instituições locais. Ainda segundo a autora:

...é preciso construir essa cidadania plena não só em relação a pais migantes e novas gerações, mas principalmente nos professores, ou melhor, professoras de nossas escolas primárias, que não são elas próprias cidadãs plenas em nossas cidades: Não vão ao cinema, ao teatro, ao concerto, não freqüentam bibliotecas, museus, exposições... (1995, p.94)

Partindo das vozes ouvidas e das imagens coletadas e aqui descritas, esperamos poder mostrar, sem moralismos e sentimentalismos, as muitas ci-

12. Aos ouvidos acostumados com a melodia e a estética de outras composições é muito difícil tolerar as manifestações do rap, cuja preocupação primeira parece ser muito mais o grito e a palavra-denúncia do que a harmonia e a cadência de outros cantos. 
dades que convivem e se opõem na cidade. Uma cidade nascida de percepções - partilhadas ou antagônicas - daqueles que nela habitam. Cidadãos, como Borges, quando recorda de uma Buenos Aires, que foi a sua:

Nasci em outra cidade que também se chamava Buenos Aires/ Recordo o ruído dos ferros do portão gradeado./ Recordo os jasmins e o algibre, coisas da nostalgia/ Recordo uma divisa rosada que um dia foi escarlate/ Recordo os lampiões de gás e o homem com o cajado/ Recordo o tempo generoso, as pessoas que chegavam sem avisar./ Naquela Buenos Aires, que me deixou, eu seria um estranho./ Sei que os únicos paraísos não proibidos ao homem são os/ Paraísos perdidos. ( 2000, p.343)

Babel, esfinge, labirinto, metáforas já conhecidas que dizem a cidade quando olhada a distância e de lugares adversos. Entretanto, quando vista na proximidade de paisagens que guardam momentos memoráveis nela vividos, são outras as imagens construídas. Benjamin retoma a Berlim de sua infância, Drummond lamenta uma Itabira de ontem, Bandeira entoa uma última canção para o Beco, Brecht pede ao citadino que apague suas pegadas, Mário de Andrade fala de Paulicéia Desvairada.

\section{REFERÊNCIAS BIBLIOGRÁFICAS}

ANDRADE, E. N. Rap e educação rap é educação. São Paulo: Summus, 1999.

ANDRADE, M. Paulicea desvairada. I.ed. São Paulo: Casa Mayenca, 1922.

AUGÉ, M. Não-lugares. introdução a uma antropologia da supermodernidade. Campinas: Papirus, 1994.

BARTHES, R. et al. Análise estrutural da narrativa. Petrópolis: Vozes, I97I .

BENJAMIN, W. Charles Baudelaire: um lírico no auge do capitalismo. São Paulo: Brasiliense, 1991. (Obras Escolhidas, 3)

Magia e técnica, arte e política. São Paulo: Brasiliense, 1985. (Obras EscoIhidas, I)

Rua de mão única. São Paulo, Brasiliense, 1987. (Obras Escolhidas, 2) 
BORGES, J. L. Obras completas, 3. São Paulo: Globo, 2000.

BOSI, E. Memória e sociedade: lembrança de velhos. São Paulo: T. A. Queiroz, 1979.

BRECHT, B. Poemas /9/3-1956. São Paulo: Ed. 34, 2000.

CALVINO, I. As Cidades invisiveis. São Paulo: Cia das Letras, 1992.

CAMPOS, M. M. Cidade e educação: repensando as relações entre escola e território. Tempo Brasileiro, Rio de Janeiro, n. 120, p.89-96, jan./mar. 1995.

CANEVACCI, M. A Cidade polifônica. São Paulo: Nobel, 1993.

CERTEAU, M. de. A Invenção do quotidiano. Petropólis: Vozes, 1994.

CHAUI, M. Cultura e democracia. São Paulo: Moderna, 1984.

DAYRELL, J. A Música entra em cena: o rap e o funk na socialização da juventude em Belo Horizonte. São Paulo: Feusp, 200 I. (mimeo)

DIETZSCH, M. J. M. Ensaiando leituras com meninos que vivem nas ruas de São Paulo. In: FREITAG, B. (org.) A Universidade em destaque: anuário de educação 97/98. Rio de Janeiro: Tempo Brasileiro, 1998. p.255-273.

Era uma vez a palavra. São Paulo, 2003. Tese (livre-doc.) Faculdade de Educação, Universidade de São Paulo.

Leituras da cidade e educação: projeto de pesquisa. São Paulo: CNPq, 2002-2004.

Ler a cidade e escrever a cidadania, Rio de Janeiro, Tempo Brasileiro, n. I 20, p.43-56, jan-mar. 1995.

Professoras dialogam com o texto literário. Cadernos de Pesquisa, São Paulo, v.34, n. 122, p.359-389, maio/ago. 2004.

Recontando histórias: vozes e silêncios de meninos de rua. Cadernos de Pesquisa, n. 104, p. I22-| 43, jul. 1998a.

GLOTZ, G. A Cidade grega. Rio de Janeiro: Difel, 1980.

GRAVES, R. The Greek myths. England: Penguin Books, 1968.

KOOLHAAS, R.; MAN. B. S, M, L, XL. New York: The Monacelli Press, 1998.

PAZ, O. El Arco y la lira. México: Fondo de Cultura Económica, 1998.

POE, E. A. O Homem na multidão. Porto Alegre: Praula, 1993. [ed. trilíngüe] 
PORTELA, E. Educação pela cidade. cidade e educação. Tempo Brasileiro, Rio de Janeiro, n. 120, p. 109-114, jan./mar.1995.

RAYMOND W. O Campo e a cidade na história e na literatura. São Paulo: Cia das Letras, 1989.

RIO, J. do. A Alma encantadora das ruas. São Paulo: Cia das Letras, 1997.

SANTOS, M. A Natureza do espaço. São Paulo: Hucitec, 1996.

TEIXEIRA, A. M. L. De como a literatura chegou à cidade e vice-versa. São Paulo, 2006. Tese (dout.) Faculdade de Educação, Universidade de São Paulo.

TONUCCI, F. La Cludad de los niños. Buenos Aires: Losada, 1996.

VILAS, M. C. P. Pensar e escrever a leitura na escola. São Paulo, 2003. Dissert. (mestr.) Faculdade de Educação, Universidade de São Paulo.

Recebido em: março 2006

Aprovado para publicação em: maio 2006 